\title{
High aldehyde dehydrogenase activity identifies cancer stem cells in human cervical cancer
}

\author{
Shu-Yan Liu ${ }^{1}$ and Peng-Sheng Zheng ${ }^{1,2}$ \\ ${ }^{1}$ Department of Reproductive Medicine, The First Affiliated Hospital of the Medical College, Xi'an Jiaotong University, Xi'an, \\ The People's Republic of China \\ ${ }^{2}$ Section of Cancer Stem Cell Research, Key Laboratory of Environment and Genes Related to Diseases, Ministry of Education \\ of the People's Republic of China, Xi'an, The People's Republic of China
}

Correspondence to: Peng-Sheng Zheng, email: zpsheng@mail.xjtu.edu.cn

Keywords: aldehyde dehydrogenase, cancer stem cells, cervical cancer, self-renewal, chemoresistance

Received: November 5, $2013 \quad$ Accepted: November 23, $2013 \quad$ Published: November 25, 2013

This is an open-access article distributed under the terms of the Creative Commons Attribution License, which permits unrestricted use, distribution, and reproduction in any medium, provided the original author and source are credited.

\section{ABSTRACT:}

High aldehyde dehydrogenase (ALDH) activity characterizes a subpopulation of cells with cancer stem cell (CSC) properties in several malignancies. To clarify whether ALDH can be used as a marker of cervical cancer stem cells (CCSCs), ALDH ${ }^{\text {high }}$ and ALDH $^{\text {low }}$ cells were sorted from 4 cervical cancer cell lines and 5 primary tumor xenografts and examined for CSC characteristics. Here, we demonstrate that cervical cancer cells with high ALDH activity fulfill the functional criteria for CSCs: (1) ALDH ${ }^{\text {high }}$ cells, unlike ALDH ${ }^{\text {low }}$ cells, are highly tumorigenic in vivo; (2) ALDH ${ }^{\text {high }}$ cells can give rise to both ALDH ${ }^{\text {high }}$ and ALDH ${ }^{\text {low }}$ cells in vitro and in vivo, thereby establishing a cellular hierarchy; and (3) ALDH ${ }^{\text {high }}$ cells have enhanced self-renewal and differentiation potentials. Additionally, ALDH ${ }^{\text {high }}$ cervical cancer cells are more resistant to cisplatin treatment than ALDH ${ }^{\text {low }}$ cells. Finally, expression of the stem cell self-renewal-associated transcription factors OCT4, NANOG, KLF4 and BMI1 is elevated in ALDH ${ }^{\text {high }}$ cervical cancer cells. Taken together, our data indicated that high ALDH activity may represent both a functional marker for CCSCs and a target for novel cervical cancer therapies.

\section{INTRODUCTION}

Cervical cancer is the second most commonly diagnosed cancer and ranks second only to breast cancer as the leading cause of cancer death in women in developing countries [1]. Based on the GLOBOCAN estimates, approximately 529,000 women worldwide were diagnosed with invasive cervical cancer, and more than half of these patients died from their disease in 2008 [2]. Cervical carcinoma development begins with the infection of the cervical epithelium by high-risk human papillomaviruses (hr-HPVs) [3-5]. Although cervical cancer can be detected in its early stages by HPV testing and Papanicolaou (Pap) smear screening and successfully eradicated through surgery, curative treatments do not yet exist for advanced, recurrent or metastatic disease [6-8].

Tumor growth and metastasis are driven by a small population of cancer stem cells (CSCs) [9]. The first extensive documentation of CSCs came from leukemia, in which only a small subset of cancer cells were shown to be capable of transferring the disease to non-obese diabetic/severe combined immunodeficient (NOD/SCID) mice [10]. This concept was then extended to solid tumors. Human breast cancers have been demonstrated to contain a population of cells with stem cell properties that display surface marker expression of $\mathrm{CD} 44^{+} / \mathrm{CD} 24^{-} /$ $\operatorname{lin}^{-}$[11]. Subsequently, CSCs have been identified and prospectively isolated using surface markers from a variety of malignancies, including brain tumors [12], melanoma [13], multiple myeloma [14], prostate cancer [15], colon cancer [16, 17], head and neck squamous cell carcinoma [18, 19] and pancreatic adenocarcinoma [20]. Due to the instability and scarcity of surface markers in solid tumors, other methodological strategies have been widely explored to identify and isolate CSCs, including side population phenotype, sphere formation and aldehyde dehydrogenase (ALDH) activity assay [21].

ALDH is a group of intracellular enzymes that oxidize aldehydes (thereby serving a detoxifying role) and convert retinol to retinoic acid, which mediates 
control over differentiation pathways [22, 23]. ALDH is highly expressed in hematopoietic stem cells and provides protection against the alkylating agent cyclophosphamide [24-27]. Increasing evidence has suggested that ALDH activity can be used either alone or in combination with cell surface markers to identify CSCs in hematologic malignancies [28] and a steadily increasing number of solid tumors, including those of the breast [29], colon [3032], bladder [33], prostate [34, 35], lung [36], pancreas [37], head and neck [38], endometrium [39], ovary [40] and melanoma [41]. Previous studies have shown that ALDH1 is expressed in cervical cancer cell lines and primary cervical cancer tissues [42-44]. However, the ability to isolate and identify cervical cancer stem cells (CCSCs) by ALDH activity has not yet been reported.

To verify whether cells with high ALDH activity are CCSCs, fluorescence activated cell sorting (FACS) and standard functional assays were used in the present study to analyze the cellular properties of $\mathrm{ALDH}^{\text {high }}$ and $\mathrm{ALDH}^{\text {low }}$ cells isolated from 4 human cervical cancer cell lines and 5 primary cervical cancers. The results indicated that a subpopulation of human cervical cancer cells with high ALDH activity possess enhanced selfrenewal capacities, differentiation potential and increased tumorigenicity, indicating that high ALDH activity may represent a marker of CSCs in cervical cancer.

\section{RESULTS}

\section{ALDH expression and activity in human cervical tissue specimens and cervical cancer cell lines}

ALDH1 expression was evaluated in normal and cancerous cervical tissues (Figure 1A). Notable differences were observed in the expression patterns of ALDH1 in the basal cells of normal human cervical tissues; these patterns were classified into 4 types: (1) No ALDH1 expression (Figure 1Aa); (2) Dot-scattered ALDH1 expression (Figure 1Ab); (3) Focal distribution of ALDH1-positive cells (Figure 1Ac); and (4) Positive ALDH1 expression in all basal cells (Figure 1Ad). Because basal cells are known to contain undifferentiated reserve cells of the normal cervix, we speculated that the ALDH1-positive basal cells may represent the stem cells of the normal cervix. A large number of ALDH1-positive cells were found in the stroma in all of the normal cervical tissues (Figure 1Aa-1Ad). Most of these ALDH1-positive cells in the normal cervical stroma are likely CD45-positive leukocytes, which have also been found in the stroma of normal breast tissues by Dr. Deng et al. [45].

ALDH1-positive cells were also found in all 53 cervical cancer tissues. Similar to ALDH1 expression in the normal cervical tissues, the expression patterns of ALDH1 in the cervical cancer tissues could be classified into 3 types: (1) Dot-scattered ALDH1 expression (Figure 1Ae); (2) Focal distribution of ALDH1-positive tumor cells (Figure 1Af); and (3) Diffuse ALDH1 expression (Figure $1 \mathrm{Ag}$ ). In this study, approximately $10 \%$ of the cervical cancer cells were ALDH1-positive, which is consistent with the notion that CSCs constitute a minority of the tumor cells. Furthermore, ALDH1-positive cells were present in each of the 19 passages of the serially xenografted tissues in NOD/SCID mice (Figure 1Ah).

The ALDEFLUOR kit was used to test the ALDH enzymatic activity in the cervical cancer cell lines. Cells were labeled with activated ALDEFLUOR reagent in the presence or absence of the ALDH inhibitor, DEAB.
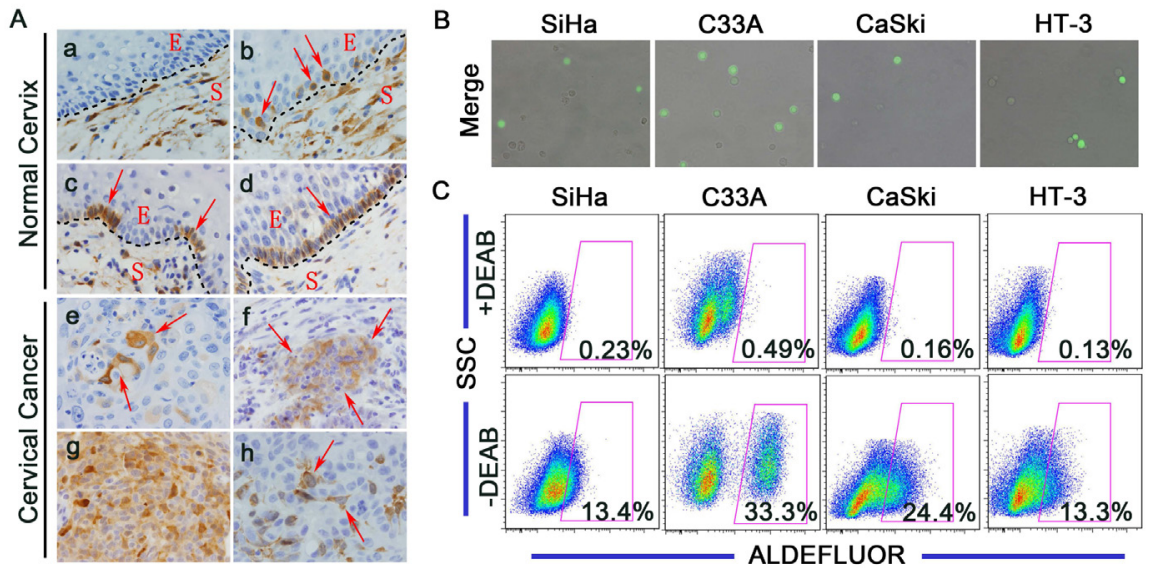

Figure 1: ALDH expression in human cervical tissue specimens and cervical cancer cell lines. A, Representative photos of immunostained specimens showing ALDH1 expression in normal cervical (a-d) and cervical cancer (e-h) tissues. a, no ALDH1positive cells; b, dot-scattered ALDH1 expression; c, focal distribution of ALDH1-positive cells; d, all basal cells of the normal cervix are ALDH1-positive; e, dot-scattered ALDH1 expression; f, focal distribution of ALDH1-positive cells; g, diffuse ALDH1 expression; h, ALDH1-positive cells in xenograft tissue from mice. Red arrows indicate ALDH1-positive cells. S, Stroma; E, Epithelium; Magnifications, $1000 \times$. B, Cells were labeled using the ALDEFLUOR kit, and ALDH ${ }^{\text {high }}$ cells (bright green fluorescence) were detected by fluorescent microscopy. C, ALDH enzyme activity in 4 cervical cancer cell lines was analyzed by flow cytometry. As a negative control, cells were treated with the specific ALDH inhibitor DEAB. The gated cells represent the ALDH ${ }^{\text {high }}$ cells. 
A drop of ALDEFLUOR-labeled cells was smeared and examined by fluorescence microscopy. Fluorescent and phase contrast images were acquired and merged. As shown in Figure 1B, each of the 4 cervical cancer cell lines (SiHa, C33A, CaSki and HT-3) contained ALDH-positive cells (indicated by the bright green fluorescence). The remaining ALDEFLUOR-labeled cells were analyzed by flow cytometry. Compared with the DEAB-treated control, high ALDH activity was detected in $13.4 \%$ of the $\mathrm{SiHa}$ cells, $33.3 \%$ of the C33A cells, $24.4 \%$ of the CaSki cells and $13.3 \%$ of the HT-3 cells (Figure 1C).

Together, these results suggest that a subpopulation of ALDH ${ }^{\text {high }}$ cells exists in normal and cancerous cervical tissues, serially xenografted cervical cancer tissues and cervical cancer cell lines, implying that ALDH may be a marker of stem cells and CSCs in cervical tissues.

\section{ALDH $^{\text {high }}$ cervical cancer cells display enhanced self-renewal capacity}

Self-renewal is a critical characteristic of stem cells and CSCs. To assess self-renewal in vitro, $\mathrm{ALDH}^{\text {high }}$ and $\mathrm{ALDH}^{\text {low }}$ cervical cancer cells were cultured in serumfree medium under conditions optimal for growing tumorspheres. As shown in Figure 2A, $\mathrm{ALDH}^{\text {high }}$ cells isolated from the 4 cervical cancer cell lines generated classical tumorspheres, while $\mathrm{ALDH}^{\text {low }}$ cells did not form tumorspheres, but only a few cell aggregates. When plated at a density of 200 cells/well in 24 -well plates (low density culture), 6.2\%, 8.5\%,6.2\% and 9\% of the $\mathrm{ALDH}^{\text {high }}$ cells from SiHa, C33A, CaSki and HT-3 cells, respectively, generated tumorspheres in the $1^{\text {st }}$ passage, while the $\mathrm{ALDH}^{\text {low }}$ cells generated no, or very rare, tumorspheres. Upon 3 consecutive passages in culture, the tumorsphere forming efficiency of the ALDH ${ }^{\text {high }}$ cells gradually increased (Figure 2B). To exclude the effects of cell aggregation, which can occur in low density cultures, cells were cultured at a density of a single cell/ well. The ALDH ${ }^{\text {high }}$ cells from $\mathrm{SiHa}, \mathrm{C} 33 \mathrm{~A}, \mathrm{CaSki}$ and HT-3 cells generated tumorspheres with an efficiency of $32.8 \%, 24.5 \%, 26.6 \%$ and $38.5 \%$, whereas the $\mathrm{ALDH}^{\text {low }}$ cells generated tumorspheres with an efficiency of $2.6 \%$, $1.6 \%, 2.6 \%$ and $4.7 \%$, respectively (Figure 2C). These data indicated that the $\mathrm{ALDH}^{\text {high }}$ cervical cancer cells have greater self-renewal capacity than the $\mathrm{ALDH}^{\text {low }}$ cells.

\section{ALDH ${ }^{\text {high }}$ cervical cancer cells have enhanced tumorigenic capacity in vivo}

One of the most important characteristics of CSCs is their powerful ability to form tumors. To determine whether the $\mathrm{ALDH}^{\text {high }}$ cells have a greater capacity to form tumors, the ALDH ${ }^{\text {high }}$ and $\mathrm{ALDH}^{\text {low }}$ cell populations were sorted from 4 cervical cancer cell lines, and limiting dilutions of the cells were subcutaneously injected into NOD/SCID mice. The tumor latency, tumor incidence and tumor volume were then monitored.

Firstly, tumor volume was monitored twice a week,

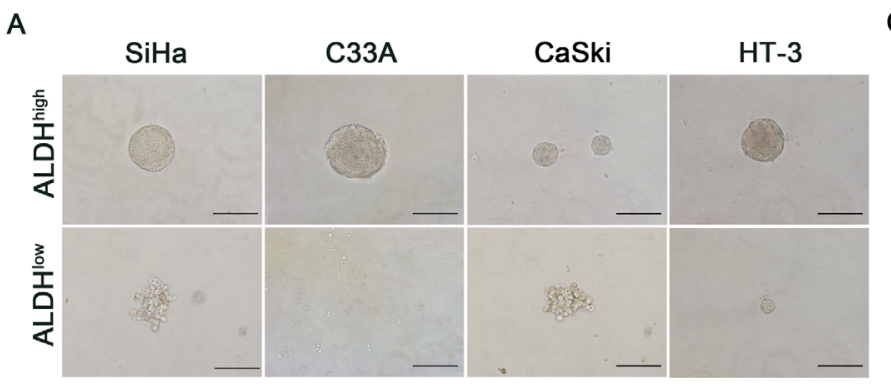

C

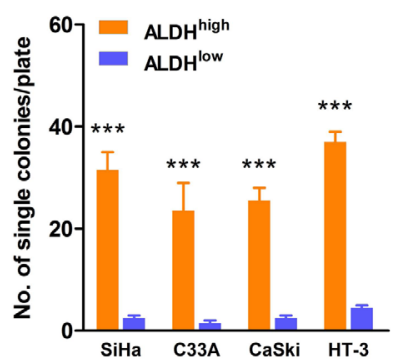

B
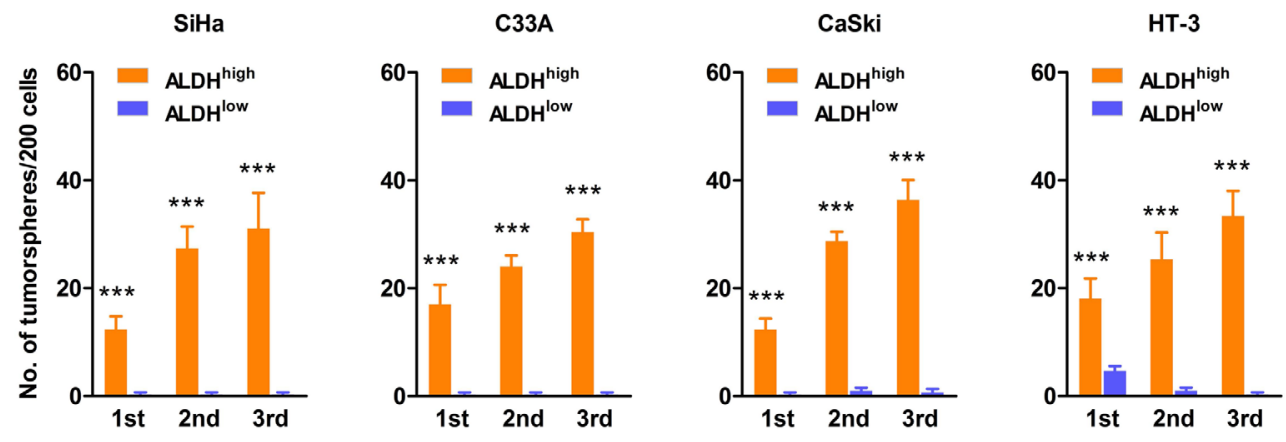

Figure 2: $\mathrm{ALDH}^{\text {high }}$ cervical cancer cells exhibit enhanced self-renewal capacity. A, Representative photos of tumorspheres formed by ALDH ${ }^{\text {high }}$ and ALDH ${ }^{\text {low }}$ cells are shown. Bar, $200 \mu \mathrm{m}$. B, The number of tumorspheres $/ 200$ cells was counted from 3 consecutive passages. C, The number of wells containing tumorspheres was counted. $* * *, p<0.001$. Data represent mean $\pm \mathrm{SD}$ of triplicate experiments. 
A
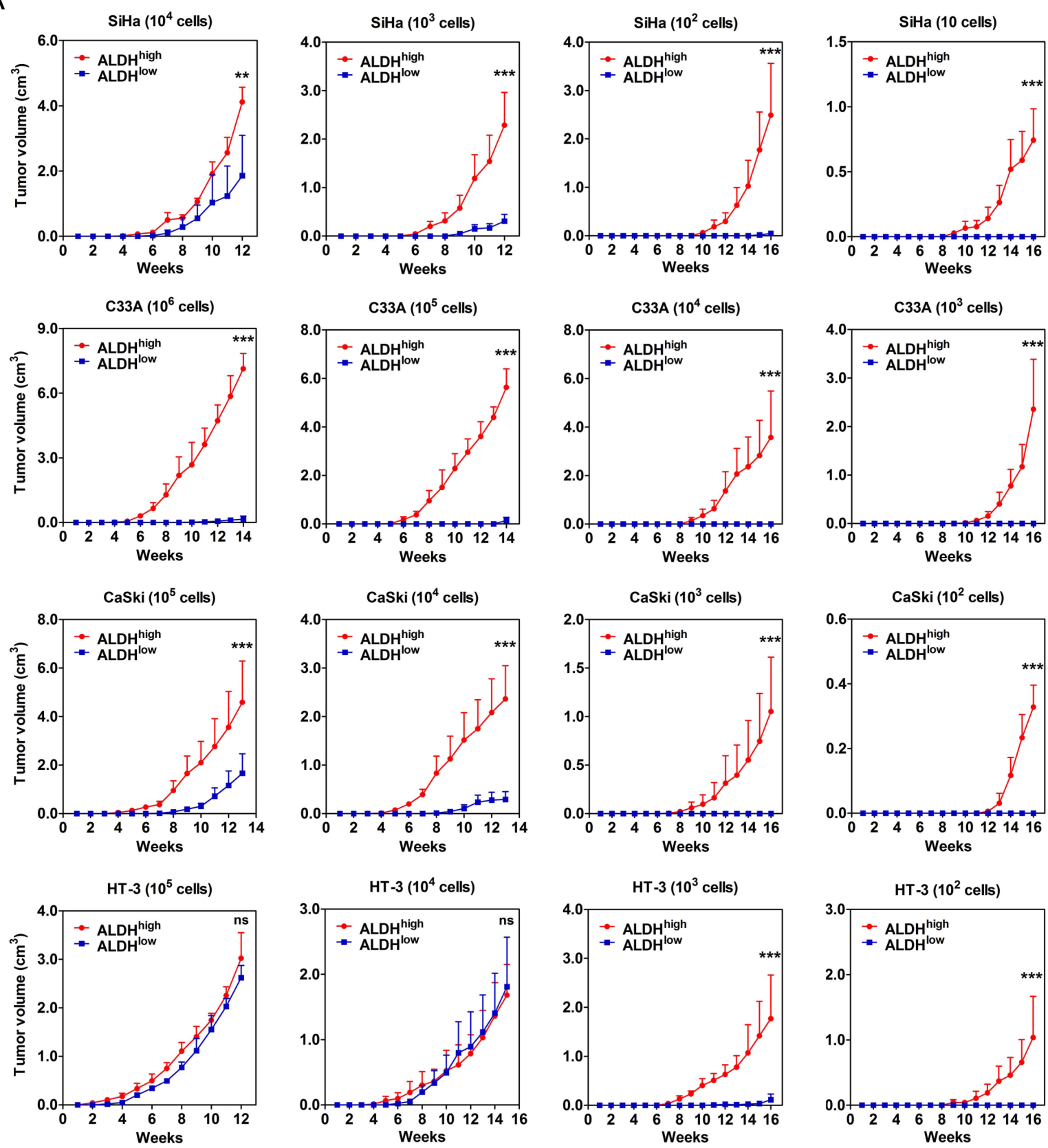

$\mathrm{SiHa}$

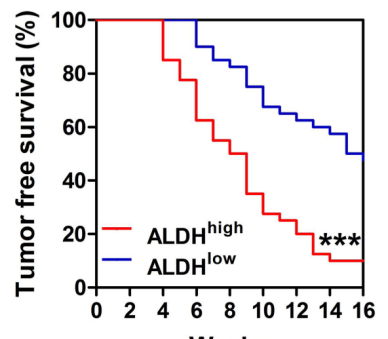

C33A

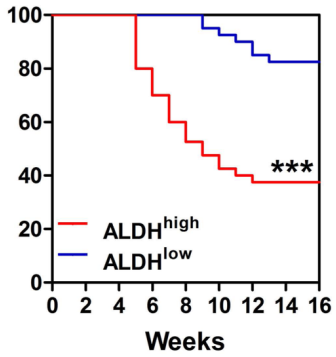

CaSki

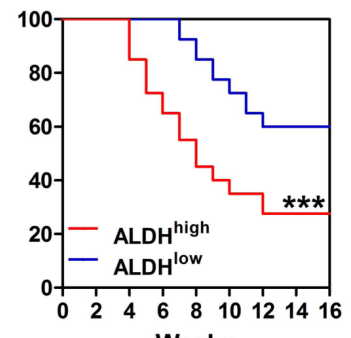

HT-3

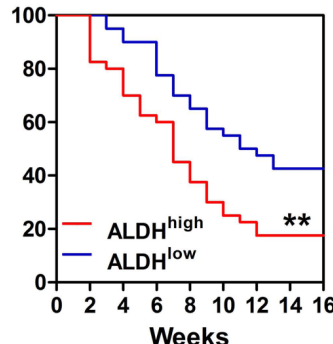

Figure 3: Tumorigencity of ALDH ${ }^{\text {high }}$ and ALDH ${ }^{\text {low }}$ cells from 4 cervical cancer cell lines in NOD/SCID mice. A, The volume of xenograft tumors formed by different numbers of $\mathrm{ALDH}^{\text {high }}$ and $\mathrm{ALDH}^{\text {low }}$ cervical cancer cells was monitored over time. B, Kaplan-Meier plots showing the tumor-free survival after injection. ns, not significant; *, $p<0.05 ; * *, p<0.01 ; * * *, p<0.001$. Data represent mean $\pm \mathrm{SD}$ of tumor volumes at different time points of 10 mice in each group. 
and the results are shown in Figure 3A. Inoculation of NOD/SCID mice with $10^{4}$ or $10^{3} \mathrm{ALDH}^{\text {high }}$ and $\mathrm{ALDH}^{\text {low }}$ SiHa cells led to tumor formation from both populations. However, the tumors formed by $\mathrm{ALDH}^{\text {high }} \mathrm{SiHa}$ cells were larger and grew faster than those formed by $\mathrm{ALDH}^{\text {low }} \mathrm{SiHa}$ cells. Furthermore, inoculation with $10^{2}$ or $10^{1} \mathrm{ALDH}^{\text {high }}$ and $\mathrm{ALDH}^{\text {low }} \mathrm{SiHa}$ cells led to tumor formation from only the $\mathrm{ALDH}^{\text {high }} \mathrm{SiHa}$ cells (Figure 3A, panel 1). In C33A cells, the $\mathrm{ALDH}^{\text {high }}$ population, but not the $\mathrm{ALDH}^{\text {low }}$ population, was capable of forming palpable tumors at each cell dose $\left(10^{6}, 10^{5}, 10^{4}\right.$ and $\left.10^{3}\right)$. However, upon sacrifice of the NOD/SCID mice, very small regions of tumor were found in the mice that had been inoculated with $10^{6}$ and $10^{5} \mathrm{ALDH}^{\text {low }} \mathrm{C} 33 \mathrm{~A}$ cells (Figure $3 \mathrm{~A}$, panel 2). Upon inoculation with $10^{5}$ or $10^{4} \mathrm{CaSki}$ cells, the $\mathrm{ALDH}^{\text {high }}$ population formed larger palpable tumors more rapidly than the $\mathrm{ALDH}^{\text {low }}$ population. However, after inoculation with $10^{3}$ or $10^{2}$ cells, the $\mathrm{ALDH}^{\text {high }} \mathrm{CaSki}$ cells, but not the $\mathrm{ALDH}^{\text {low }}$ CaSki cells, were capable of forming palpable tumors (Figure 3A, panel 3). In HT-3 cells, $10^{5}$ or $10^{4}$ of the $\mathrm{ALDH}^{\text {high }}$ and $\mathrm{ALDH}^{\text {low }}$ cells formed similarly sized palpable tumors almost simultaneously. When the cell dose was decreased to $10^{3}$ or $10^{2}$, ALDH ${ }^{\text {high }}$ HT-3 cells could form palpable tumors, while ALDH ${ }^{\text {low }}$ HT-3



Figure 4: $\mathrm{ALDH}^{\text {high }}$ cervical cancer cells are capable of differentiating in vitro and in vivo. A-D, $\mathrm{ALDH}^{\text {high }}$ and $\mathrm{ALDH}{ }^{\mathrm{low}}$ cells were isolated from the $\mathrm{SiHa}$ (A), C33A (B), CaSki (C) or HT-3 (D) cell lines and cultured in DMEM medium supplemented with 10\% FBS for 2 weeks. The ALDH enzyme activity was then analyzed by flow cytometry. Cells treated with DEAB served as a negative control. The gated cells represent the ALDH ${ }^{\text {high }}$ cells. E, Expression of ALDH1 was detected by IHC in xenograft tumors from ALDH ${ }^{\text {high }}$ and ALDH ${ }^{\text {low }}$ cells. Red arrows indicate ALDH1-positive cells 
cells formed very small or no palpable tumors (Figure 3A, panel 4).

Tumor latency was monitored after injection of sorted cells into the NOD/SCID mice and was defined by the period of time during which the mice remained tumor-free (Figure $3 \mathrm{~B}$ ). ALDH ${ }^{\text {high }} \mathrm{SiHa}$ cells exhibited a significantly shorter tumor-free period; for instance, the shortest tumor-free period for ALDH ${ }^{\text {high }}$ cells was 4 weeks, as compared to the 6 week latent period for $\mathrm{ALDH}^{\text {low }}$ cells. $\mathrm{ALDH}^{\text {high }} \mathrm{SiHa}$ cells also exhibited a lower tumor-free rate ( $10 \%$ in $\mathrm{ALDH}^{\text {high }}$ cells versus $47.5 \%$ in $\mathrm{ALDH}^{\text {low }}$ cells) than $\mathrm{ALDH}^{\text {low }} \mathrm{SiHa}$ cells $(p<0.001)$. Similarly, $\mathrm{ALDH}^{\text {high }}$ C33A cells displayed a significantly shorter tumor-free period (5 weeks in $\mathrm{ALDH}^{\text {high }}$ cells versus 9 weeks in $\mathrm{ALDH}^{\text {low }}$ cells) and a lower tumor-free rate $(37.5 \%$ in $\mathrm{ALDH}^{\text {high }}$ cells versus $82.5 \%$ in $\mathrm{ALDH}^{\text {low }}$ cells) compared with $\mathrm{ALDH}^{\text {low }} \mathrm{C} 33 \mathrm{~A}$ cells $(p<0.001)$. $\mathrm{ALDH}^{\text {high }} \mathrm{CaSki}$ cells exhibited a significantly shorter tumor-free period (4 weeks in $\mathrm{ALDH}^{\text {high }}$ cells versus 7 weeks in $\mathrm{ALDH}^{\text {low }}$ cells) and a lower tumor-free rate $\left(27.5 \%\right.$ in $\mathrm{ALDH}^{\text {high }}$ cells versus $60 \%$ in $\mathrm{ALDH}^{\text {low }}$ cells) compared with $\mathrm{ALDH}^{\text {low }}$ CaSki cells $(p<0.001)$. ALDH ${ }^{\text {high }}$ HT-3 cells also showed a significantly shorter tumor-free period ( 2 weeks in $\mathrm{ALDH}^{\text {high }}$ cells versus 3 weeks in $\mathrm{ALDH}^{\text {low }}$ cells) and a lower tumor-free rate $\left(17.5 \%\right.$ in $\mathrm{ALDH}^{\text {high }}$ cells versus $42.5 \%$ in $\mathrm{ALDH}^{\text {low }}$ cells) compared with ALDH ${ }^{\text {low }}$ HT-3 cells $(p<0.01)$.

The tumor incidence from $\mathrm{ALDH}^{\text {high }}$ and $\mathrm{ALDH}^{\text {low }}$ populations in all 4 cervical cancer cell lines is summarized in Table 1. The tumor-initiating frequency of $\mathrm{ALDH}^{\text {high }} \mathrm{SiHa}$ cells was $1 / 11$, which was 51.4 -fold higher than that of ALDH ${ }^{\text {low }} \mathrm{SiHa}$ cells $(1 / 586 ; p<0.001)$. The tumor-initiating frequency of $\mathrm{ALDH}^{\text {high }} \mathrm{C} 33 \mathrm{~A}$ cells $(1: 27,331)$ was 39.8 -fold higher than that of $\mathrm{ALDH}^{\text {low }}$ C33A cells $(1: 1,086,487 ; p<0.001)$. The tumor-initiating frequency of $\mathrm{ALDH}^{\text {high }}$ CaSki cells was 1/737, which was 17.4-fold higher than that of $\mathrm{ALDH}^{\text {low }} \mathrm{CaSki}$ cells $(1 / 12,788 ; p<0.001)$, and the tumor-initiating frequency of ALDH ${ }^{\text {high }}$ HT-3 cells (1:234) was 14.7-fold higher than that of ALDH ${ }^{\text {low }}$ HT-3 cells $(1: 3,434 ; p<0.001)$.

Together, these results from the tumor formation assays in NOD/SCID mice suggest that $\mathrm{ALDH}^{\text {high }}$ cervical cancer cells have a more rapid tumor growth rate, shorter tumor latency, lower tumor-free rate and higher tumor-

A
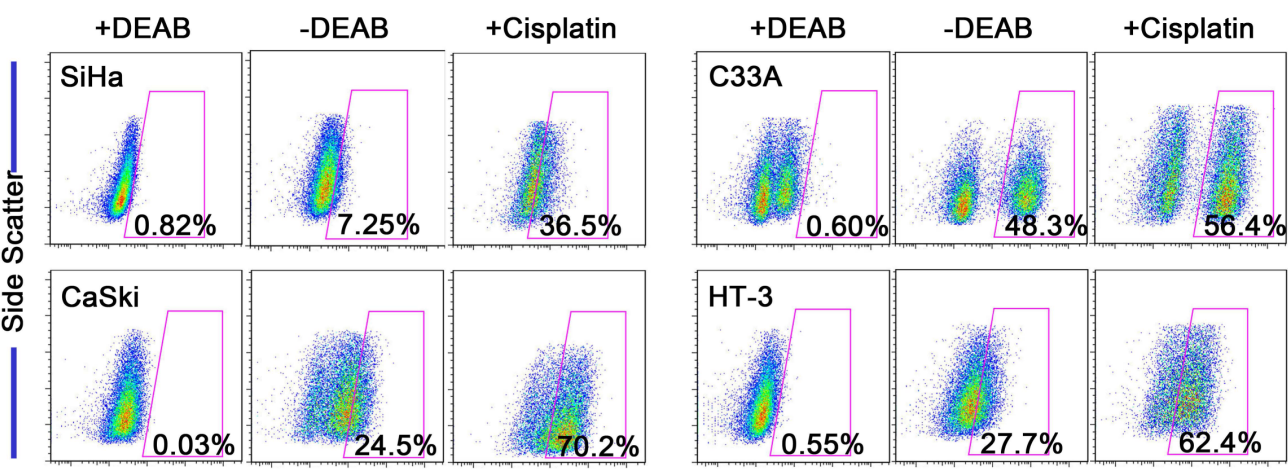

ALDEFLUOR

B

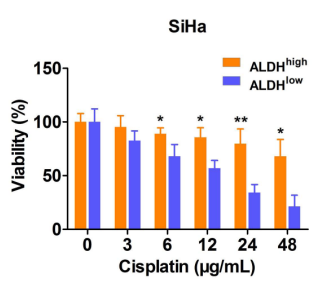

C

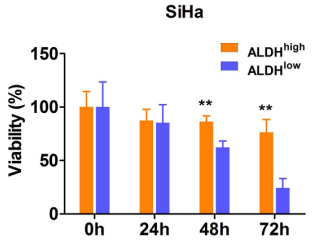

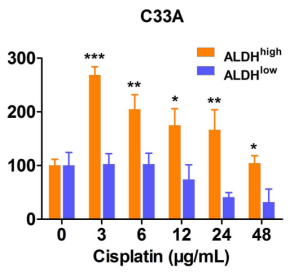

C33A

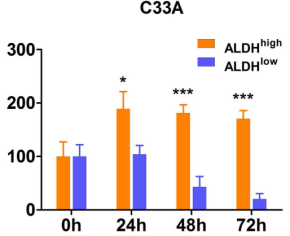

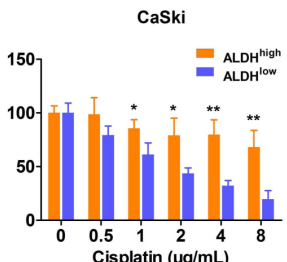
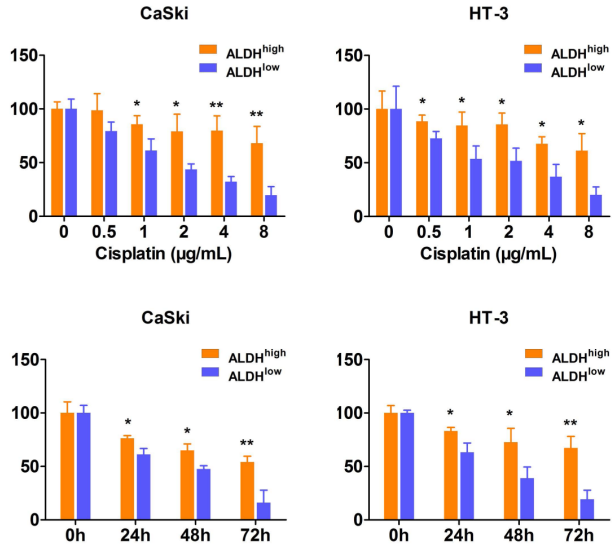

HT -3

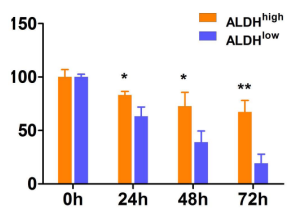

Figure 5: $\mathbf{A L D H}^{\text {high }}$ cells are more resistant to cisplatin than $\mathbf{A L D H}{ }^{\text {low }}$ cells. A, The ALDH activity of the cervical cancer cell lines was analyzed after exposure to cisplatin ( $3 \mu \mathrm{g} / \mathrm{mL}$ for SiHa and C33A cells or $1 \mu \mathrm{g} / \mathrm{mL}$ for CaSki and HT-3 cells) for 3 days. The percentage of $\mathrm{ALDH}^{\text {high }}$ cells in the 4 cervical cancer cell lines was analyzed by flow cytometry following exposure to cisplatin for 3 days. B, Cell viability of the $\mathrm{ALDH}^{\text {high }}$ and $\mathrm{ALDH}^{\text {low }}$ cervical cancer cells was measured using an MTT assay after treatment with different concentrations of cisplatin for $24 \mathrm{~h}$. C, Cell viability of the $\mathrm{ALDH}^{\text {high }}$ and the ALDH ${ }^{\text {low }}$ cervical cancer cells was measured using an MTT assay after treatment with a constant dose of cisplatin for $0,24,48$ or 72 h. $*, p<0.05 ; * *, p<0.01 ; * * *, p<0.001$. Data represent mean $\pm \mathrm{SD}$ of triplicate experiments. 
Table 1: Tumorigenic capacity of $\mathrm{ALDH}^{\text {high }}$ and $\mathrm{ALDH}^{\text {low }}$ cells in NOD/SCID mice from 4 cervical cancer cell lines

\begin{tabular}{|c|c|c|c|c|c|c|c|c|c|}
\hline \multirow{2}{*}{ Cell line } & \multirow{2}{*}{ Sub-population } & \multicolumn{6}{|c|}{ Cell dose } & \multirow{2}{*}{$\begin{array}{l}\text { Tumor-Initiating frequency } \\
\text { (95\% Interval) }\end{array}$} & \multirow{2}{*}{$\mathrm{p}$ value } \\
\hline & & $10^{6}$ & $10^{5}$ & $10^{4}$ & $10^{3}$ & $10^{2}$ & 10 & & \\
\hline \multirow{2}{*}{$\mathrm{SiHa}$} & ALDH $^{\text {high }}$ & - & - & $10 / 10$ & $10 / 10$ & $10 / 10$ & $6 / 10$ & $1: 11(1: 25-1: 5)$ & \multirow{2}{*}{$<0.001$} \\
\hline & $\mathrm{ALDH}^{\text {low }}$ & -- & -- & $10 / 10$ & $7 / 10$ & $4 / 10$ & $0 / 10$ & $1: 586(1: 1,162-1: 295)$ & \\
\hline \multirow[b]{2}{*}{$\mathrm{C} 33 \mathrm{~A}$} & $\mathrm{ALDH}^{\text {high }}$ & $10 / 10$ & $9 / 10$ & $4 / 10$ & $2 / 10$ & -- & -- & $1: 27,331(1: 57,546-1: 12,981)$ & \multirow[b]{2}{*}{$<0.001$} \\
\hline & $\mathrm{ALDH}^{\text {low }}$ & $6 / 10$ & $1 / 10$ & $0 / 10$ & $0 / 10$ & -- & -- & $\begin{array}{l}1: 1,086,487(1: 2,331,530- \\
1: 506,300)\end{array}$ & \\
\hline \multirow{2}{*}{ CaSki } & $\mathrm{ALDH}^{\text {high }}$ & -- & $10 / 10$ & $10 / 10$ & $7 / 10$ & $2 / 10$ & -- & $1: 737(1: 1,496-1: 363)$ & \multirow{2}{*}{$<0.001$} \\
\hline & $\mathrm{ALDH}^{\text {low }}$ & -- & $10 / 10$ & $6 / 10$ & $0 / 10$ & $0 / 10$ & -- & $1: 12,788(1: 28,040-1: 5,833)$ & \\
\hline \multirow{2}{*}{ HT-3 } & $\mathrm{ALDH}^{\text {high }}$ & -- & $10 / 10$ & $10 / 10$ & $10 / 10$ & $3 / 10$ & -- & $1: 234(1: 520-1: 105)$ & \multirow{2}{*}{$<0.001$} \\
\hline & $\mathrm{ALDH}^{\text {low }}$ & - & $10 / 10$ & $9 / 10$ & $4 / 10$ & $0 / 10$ & -- & $1: 3,434(1: 6,968-1: 1,692)$ & \\
\hline
\end{tabular}

initiating frequency than $\mathrm{ALDH}^{\text {low }}$ cells. Therefore, $\mathrm{ALDH}^{\text {high }}$ cervical cancer cells have a potent ability to form tumors in vivo.

\section{ALDH $^{\text {high }}$ cells, but not ALDH ${ }^{\text {low }}$ cells, have the ability to differentiate in vitro and in vivo}

One characteristic of $\mathrm{CSCs}$ is the capacity to differentiate into non-CSCs and give rise to the heterogeneous tumor cell populations. To determine whether $\mathrm{ALDH}^{\text {high }}$ cells are capable of differentiation in vitro, $\mathrm{ALDH}^{\text {high }}$ and $\mathrm{ALDH}^{\text {low }}$ cells were cultured separately in DMEM medium supplemented with $10 \%$ FBS for 2 weeks. After incubation, the cultured populations were analyzed using the ALDEFLUOR assay (Figure 4A-4D). Approximately $90 \%$ of the ALDH ${ }^{\text {high }}$ SiHa cells differentiated into ALDH ${ }^{\text {low }}$ cells, and only $10 \%$ of the cells remained strongly ALDH-positive. However,
A

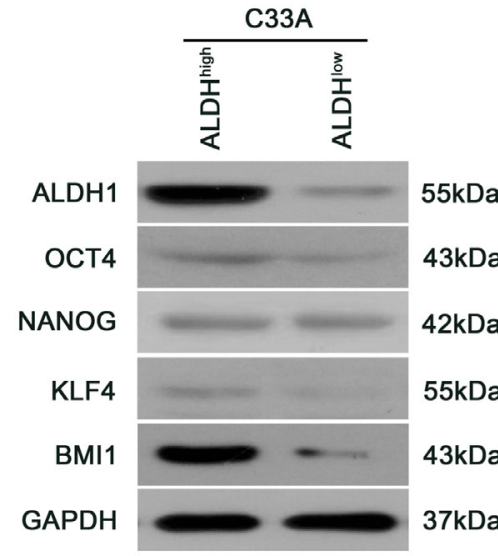

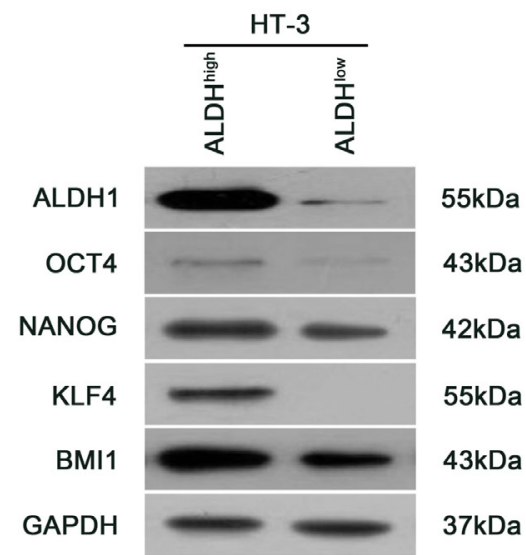

B

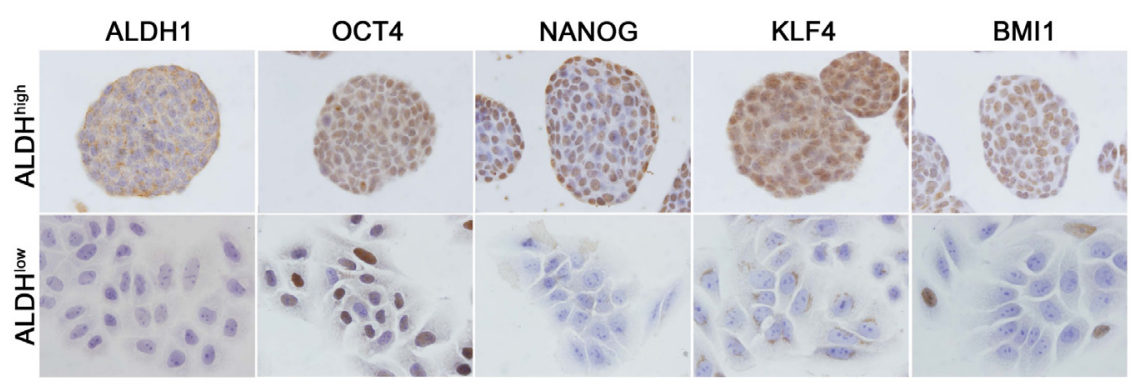

Figure 6: Expression of stem cell-associated markers in $\mathbf{A L D H}{ }^{\text {high }}$ and $\mathbf{A L D H}{ }^{\text {low }}$ cells. A, Western blot analysis of the protein levels of the stem cell-associated transcription factors OCT4, NANOG, KLF4 and BMI1 in the ALDHhigh and ALDHlow subpopulations from C33A and HT-3 cells. GAPDH was used as a loading control. B, The expression of stem cell-associated transcription factors in tumorspheres formed by ALDHhigh and ALDHlow SiHa cells was measured by IHC analysis. 
greater than $99 \%$ of the $\mathrm{ALDH}^{\text {low }} \mathrm{SiHa}$ cells retained the ALDH $^{\text {low }}$ phenotype (Figure 4A). Similarly, 57.2\% of the $\mathrm{ALDH}^{\text {high }} \mathrm{C} 33 \mathrm{~A}$ cells (Figure $\left.4 \mathrm{~B}\right), 72.1 \%$ of the $\mathrm{ALDH}^{\text {high }}$ CaSki cells (Figure 4C) and $75.9 \%$ of the ALDH ${ }^{\text {high }}$ HT3 cells (Figure 4D) generated ALDH ${ }^{\text {low }}$ cells. However, $98.52 \%$ of the ALDH ${ }^{\text {low }}$ C33A cells (Figure 4B), 99.45\% of the ALDH ${ }^{\text {low }}$ CaSki cells (Figure $4 \mathrm{C}$ ) and $99.86 \%$ of the ALDH ${ }^{\text {low }}$ HT-3 cells (Figure 4D) maintained the ALDH ${ }^{\text {low }}$ phenotype. Notably, $1.48 \%$ of the $\mathrm{ALDH}^{\text {low }} \mathrm{C} 33 \mathrm{~A}$ cells generated $\mathrm{ALDH}^{\text {high }}$ cells, which was a larger fraction than the other cell lines. Because C33A cells contain a larger population of $\mathrm{ALDH}^{\text {high }}$ cells and higher ALDH activity than the other cell lines, this proportion of $\mathrm{ALDH}^{\text {high }}$ cells may have resulted from errors during the cell sorting manipulation.

The differentiation capacity of $\mathrm{ALDH}^{\text {high }}$ and $\mathrm{ALDH}^{\text {low }}$ cells was also assessed in vivo. In the tumors formed by $\mathrm{ALDH}^{\text {high }}$ cells, a few ALDH1-positive cells and many ALDH1-negative cells were found, indicating that $\mathrm{ALDH}^{\text {high }}$ cells were able to generate $\mathrm{ALDH}^{\text {high }}$ cells through self-renewal and to generate $\mathrm{ALDH}^{\text {low }}$ cells through differentiation (Figure 4E, upper panel). However, in the tumors formed by $\mathrm{ALDH}^{\text {low }}$ cells, no ALDH1positive cells were found, indicating that $\mathrm{ALDH}^{\text {low }}$ cells did not have the ability to differentiate (Figure 4E, lower panel).

Taken together, these data demonstrate that $\mathrm{ALDH}^{\text {high }}$ cervical cancer cells have the ability to differentiate both in vitro and in vivo. Thus, $\mathrm{ALDH}^{\text {high }}$ cervical cancer cells establish the cellular hierarchy in tumors through selfrenewal and differentiation.

\section{ALDH $^{\text {high }}$ cells are more resistant to cisplatin than ALDHlow cells}

The resistance of CSCs to current chemotherapeutics is thought to be responsible for cancer recurrence and metastasis [46]. Because cisplatin is one of the most commonly used chemotherapeutic drugs in the treatment of cervical cancer, we tested the effects of cisplatin on $\mathrm{ALDH}^{\text {high }}$ and $\mathrm{ALDH}^{\text {low }}$ cervical cancer cells. After treatment with cisplatin, the population of $\mathrm{ALDH}^{\text {high }}$ cells expanded from $7.25 \%$ to $36.5 \%$ in $\mathrm{SiHa}$ cells, $48.3 \%$ to $56.4 \%$ in C33A cells, $24.5 \%$ to $70.2 \%$ in CaSki cells and $27.7 \%$ to $62.4 \%$ in HT-3 cells (Figure 5A). These data suggested that the ALDH ${ }^{\text {high }}$ cells, but not the ALDH ${ }^{\text {low }}$ cervical cancer cells, are resistant to cisplatin treatment.

Furthermore, $\mathrm{ALDH}^{\text {high }}$ and $\mathrm{ALDH}^{\text {low }}$ cells isolated from 4 cervical cancer cell lines were exposed to different concentrations of cisplatin for $24 \mathrm{~h}$, and cell viability was determined using an MTT assay. Cisplatin caused dosedependent decreases in the viability of both the $\mathrm{ALDH}^{\text {high }}$ and the $\mathrm{ALDH}^{\text {low }}$ cervical cancer cells (Figure 5B). $\mathrm{ALDH}^{\text {high }} \mathrm{SiHa}$ cells were significantly more resistant to cisplatin concentrations of $\geq 6 \mu \mathrm{g} / \mathrm{mL}$ than the $\mathrm{ALDH}^{\text {low }}$ $\mathrm{SiHa}$ cells. $\mathrm{ALDH}^{\text {high }} \mathrm{CaSki}$ cells were significantly more resistant to $\geq 1 \mu \mathrm{g} / \mathrm{mL}$ cisplatin than the $\mathrm{ALDH}^{\text {low }}$ CaSki cells. ALDH ${ }^{\text {high }}$ HT-3 cells were significantly more resistant to concentrations of $\geq 0.5 \mu \mathrm{g} / \mathrm{mL}$ cisplatin than the $\mathrm{ALDH}^{\text {low }}$ HT-3 cells. These results indicated that ALDH ${ }^{\text {high }}$ cells are more resistant to cisplatin than $\mathrm{ALDH}^{\text {low }}$ cells when exposed to the proper concentration for a limited period of time. The viability of the $\mathrm{ALDH}^{\text {high }} \mathrm{C} 33 \mathrm{~A}$ cells was significantly greater than that of the ALDH ${ }^{\text {low }}$ cells after exposure to any concentration of cisplatin. Cisplatin caused a dose-dependent decrease in the viability of the $\mathrm{ALDH}^{\text {low }} \mathrm{C} 33 \mathrm{~A}$ cells. Surprisingly, the viability of the $\mathrm{ALDH}^{\text {high }} \mathrm{C} 33 \mathrm{~A}$ cells was significantly enhanced after exposure to cisplatin compared with cells that had not been treated with cisplatin.

Cell viability was also determined by the MTT assay after exposure to constant concentration of cisplatin for 24 , 48 , or $72 \mathrm{~h}$ (Figure 5C). Cisplatin caused a time-dependent decrease in the viability of both $\mathrm{ALDH}^{\text {high }}$ and $\mathrm{ALDH}^{\text {low }}$ cells from the $\mathrm{SiHa}, \mathrm{CaSki}$ and HT-3 cells. ALDH ${ }^{\text {high }} \mathrm{SiHa}$ cells were significantly more resistant to $\geq 48 \mathrm{~h}$ of treatment with cisplatin than ALDH ${ }^{\text {low }}$ cells. In the CaSki and HT-3 cells, $\mathrm{ALDH}^{\text {high }}$ cells were significantly more resistant than $\mathrm{ALDH}^{\text {low }}$ cells to cisplatin treatment for $\geq 24 \mathrm{~h}$. The results from these 3 cell lines indicate that $\mathrm{ALDH}^{\text {high }}$ cells are more resistant to constant concentration of cisplatin than $\mathrm{ALDH}^{\text {low }}$ cells for certain periods of time. The viability of
A

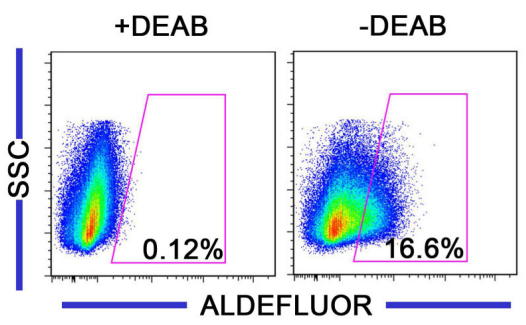

B

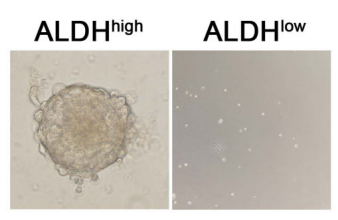

C

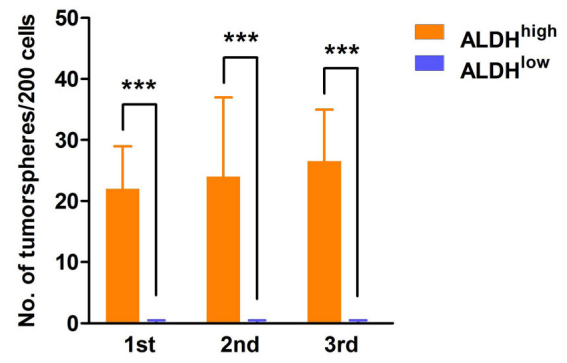

Figure 7: Characteristics of ALDH ${ }^{\text {high }}$ cells from primary cervical cancers. A, The ALDH enzyme activity of primary cervical cancer cells was analyzed by flow cytometry. B, Representative photos of tumorspheres formed by ALDH ${ }^{\text {high }}$ and ALDH ${ }^{\text {low }}$ cells sorted from primary cervical cancer are shown. C, The number of tumorspheres formed by ALDH ${ }^{\text {high }}$ and ALDH ${ }^{\text {low }}$ cells isolated from the primary cervical cancer was counted from 3 consecutive passages. ${ }^{* *}, p<0.001$. Data represent mean $\pm \mathrm{SD}$ of triplicate experiments. 
Table 2: Tumorigenic capacity of $\mathrm{ALDH}^{\text {high }}$ and $\mathrm{ALDH}{ }^{\text {low }}$ cells in NOD/SCID mice from primary tumor of cervix

\begin{tabular}{|c|c|c|c|c|c|c|c|}
\hline \multirow{2}{*}{ Primary tumor } & \multirow{2}{*}{ Sub-population } & \multicolumn{4}{|c|}{ Cell dose } & \multirow{2}{*}{$\begin{array}{l}\text { Tumor-Initiating frequency } \\
(95 \% \text { Interval })\end{array}$} & \multirow{2}{*}{$\mathrm{p}$ value } \\
\hline & & $10^{6}$ & $10^{5}$ & $10^{4}$ & $10^{3}$ & & \\
\hline \multirow{2}{*}{ PT1 } & $\mathrm{ALDH}^{\text {high }}$ & $5 / 5$ & $4 / 5$ & $3 / 5$ & $1 / 5$ & $1: 30,680(1: 85,460-1: 11,014)$ & \multirow{2}{*}{$<0.001$} \\
\hline & $\mathrm{ALDH}^{\text {low }}$ & $3 / 5$ & $1 / 5$ & $1 / 5$ & $0 / 5$ & $1: 733,639(1: 1,978,007-1: 272,105)$ & \\
\hline \multirow{2}{*}{ PT2 } & $\mathrm{ALDH}^{\text {high }}$ & - & $5 / 5$ & $2 / 5$ & $0 / 5$ & $1: 20,275(1: 62,492-1: 6,579)$ & \multirow{2}{*}{$<0.001$} \\
\hline & $\mathrm{ALDH}^{\text {low }}$ & $2 / 5$ & $1 / 5$ & $0 / 5$ & - & $1: 1,462107(1: 4,770,331-1: 448,136)$ & \\
\hline \multirow{2}{*}{ PT3 } & $\mathrm{ALDH}^{\text {high }}$ & - & $5 / 5$ & $2 / 5$ & $1 / 5$ & $1: 14,294(1: 44,503-1: 4,591)$ & \multirow{2}{*}{0.012} \\
\hline & $\mathrm{ALDH}^{\text {low }}$ & $5 / 5$ & $3 / 5$ & $1 / 5$ & $0 / 5$ & $1: 93,382(1: 263,758-1: 33,062)$ & \\
\hline \multirow{2}{*}{ PT4 } & $\mathrm{ALDH}^{\text {high }}$ & - & $5 / 5$ & $4 / 5$ & $3 / 5$ & $1: 3,596(1: 9,879-1: 1,309)$ & \multirow{2}{*}{$<0.001$} \\
\hline & $\mathrm{ALDH}^{\text {low }}$ & $3 / 5$ & $2 / 5$ & $0 / 5$ & - & $1: 722,444(1: 1,945,037-1: 268,337)$ & \\
\hline \multirow{2}{*}{ PT5 } & $\mathrm{ALDH}^{\text {high }}$ & $4 / 5$ & $2 / 5$ & $0 / 5$ & - & $1: 462,760(1: 1,216,059-1: 176,099)$ & \multirow{2}{*}{0.008} \\
\hline & $\mathrm{ALDH}^{\text {low }}$ & $1 / 5$ & $0 / 5$ & - & - & $1: 4,983,289(1: 35,191,497-1: 705,659)$ & \\
\hline
\end{tabular}

$\mathrm{ALDH}^{\text {high }}$ C33A cells was significantly greater than that of $\mathrm{ALDH}^{\text {low }}$ cells after exposure to cisplatin. Cisplatin caused a time-dependent decrease in the viability of $\mathrm{ALDH}^{\text {low }}$ C33A cells, while the viability of $\mathrm{ALDH}^{\text {high }} \mathrm{C} 33 \mathrm{~A}$ cells was significantly enhanced following exposure to cisplatin compared to cells that had not been treated with cisplatin.

In summary, these results suggest that $\mathrm{ALDH}{ }^{\text {high }}$ cervical cancer cells are more resistant to chemotherapy than $\mathrm{ALDH}^{\text {low }}$ cells.

\section{ALDH ${ }^{\text {high }}$ cells express high levels of stem cell- associated markers}

Stem cell-related transcription factors are important for maintaining the self-renewal of embryonic stem cells. To clarify whether the ALDH ${ }^{\text {high }}$ cervical cancer cells express stem cell-related transcription factors, western blot analysis was performed to assess the expression of OCT4, NANOG, KLF4 and BMI1 in ALDH ${ }^{\text {high }}$ and ALDH ${ }^{\text {low }}$ cells. ALDH ${ }^{\text {high }} \mathrm{C} 33 \mathrm{~A}$ and HT-3 cells were found to express higher levels of OCT4, NANOG, KLF4 and BMI1 than $\mathrm{ALDH}^{\text {low }}$ cells (Figure 6A). IHC analysis was also performed on the tumorspheres formed by the $\mathrm{ALDH}^{\text {high }}$ and $\mathrm{ALDH}^{\text {low }} \mathrm{SiHa}$ cells to evaluate the expression of stem cell-associated markers (Figure 6B). Similar to the western blot analysis, the stem cell-associated transcription factors OCT4, NANOG, KLF4 and BMI1 were detected in the tumorspheres formed by the $\mathrm{ALDH}^{\text {high }} \mathrm{SiHa}$ cells but not the $\mathrm{ALDH}^{\text {low }} \mathrm{SiHa}$ cells. These data indicate that ALDH ${ }^{\text {high }}$ cervical cancer cells display a nuclear stemness signature.

\section{ALDH $^{\text {high }}$ cells from primary cervical cancers possess CSC characteristics}

Our data suggest that ALDH ${ }^{\text {high }}$ cells from cervical cancer cell lines display characteristics of CSCs. However, whether $\mathrm{ALDH}^{\text {high }}$ cells derived from primary cervical cancers possess the same characteristics remained unknown. To address this question, primary cervical cancer tissues were processed into single cell suspensions and injected subcutaneously into NOD/SCID mice to create tumor xenografts. Only 5 out of 28 primary cervical cancer specimens were successfully serially transplanted for 5 generations; the estimated engraftment rate was $18 \%$. The generated xenografts were resected and dissociated into single cell suspensions. Cells were plated in 24well plates at a density of $10^{3}$ cells/well and cultured for tumorsphere formation. All tumorspheres generated from the same cervical cancer tissue were collected, digested into single cell suspensions, labeled with the ALDEFLUOR kit, analyzed and sorted by FACS.

A subpopulation of ALDH ${ }^{\text {high }}$ cells $(11-23 \%)$ was detected in all 5 of the primary tumors tested (Figure 7A). The $10 \%$ of the cell population with the highest and the lowest ALDH activity were sorted as the ALDH ${ }^{\text {high }}$ and the $\mathrm{ALDH}^{\text {low }}$ cells, respectively, for the subsequent experiments. As shown in Figure 7B, the ALDH ${ }^{\text {high }}$, but not the $\mathrm{ALDH}^{\text {low}}$, primary cervical cancer cells were capable of generating tumorspheres in suspension culture. $\mathrm{ALDH}^{\text {high }}$ cells formed tumorspheres with a frequency of approximately $10 \%$ in 3 consecutive passages (Figure $7 \mathrm{C}$ ), while $\mathrm{ALDH}^{\text {low }}$ cells did not generate tumorspheres (but did generate some cell aggregates). These data suggest that the $\mathrm{ALDH}^{\text {high }}$ primary cervical cancer cells have the ability to self-renew.

To study the tumor formation capacity of the $\mathrm{ALDH}^{\text {high }}$ and the $\mathrm{ALDH}^{\text {low }}$ primary cervical cancer cells, $10^{6}, 10^{5}, 10^{4}$ or $10^{3}$ cells were subcutaneously injected into NOD/SCID mice, and the mice were monitored for tumor growth for 20 weeks. As summarized in Table 2, the $\mathrm{ALDH}^{\text {high }}$ primary cervical cancer cells exhibited enhanced tumorigenicity compared with the ALDH ${ }^{\text {low }}$ cells. Among the 5 primary tumor samples, the tumor-initiating frequency of the $\mathrm{ALDH}^{\text {high }}$ cells was as high as 6-200 times that of the ALDH ${ }^{\text {low }}$ cells (Table 2). Furthermore, the 
tumors generated from ALDH ${ }^{\text {high }}$ cells were significantly larger and grew faster than the tumors derived from their $\mathrm{ALDH}^{\text {low }}$ counterparts. These results indicate that ALDH activity may be a functional marker of CSCs in primary cervical cancer.

\section{DISCUSSION}

Several approaches have been utilized to identify CSCs from various human malignancies, including cell surface markers, side population phenotype, spheres formation and ALDH activity assays [21]. ALDH activity (measured using the ALDEFLUOR assay) was first used to isolate leukemia stem cells [28]. Subsequently, ALDH activity has been successfully used as a CSC marker for many solid tumors, including breast [29], colon [30, 31], bladder [33], prostate [34], lung [36], head and neck [38], endometrium [39], ovary [40] and thyroid [47]. Therefore, ALDH activity may have potential as a promising universal marker for the identification and isolation of stem cells from various solid tumors. However, previous reports have not indicated whether ALDH activity can also be used as a CSC marker in cervical cancer.

In the present study, the ALDH ${ }^{\text {high }}$ cells isolated from 4 cervical cancer cell lines and 5 primary cervical cancer xenografts were demonstrated to fulfill the functional criteria for CSCs. Firstly, using the tumorsphere formation assay, ALDH ${ }^{\text {high }}$ cervical cancer cells were found to have self-renewal capacity. ALDH ${ }^{\text {high }}$ cells formed significantly more tumorspheres in both single cell culture and low density cell culture than ALDH ${ }^{\text {low }}$ cells. Furthermore, $\mathrm{ALDH}^{\text {high }}$ cells formed more tumorspheres in single cell culture than in low density cell culture (Figure 2B and 2C). Similar results have been reported for mammospheres, and cell aggregation in the low density cell cultures might contribute to the decreased formation of tumorspheres [29]. Secondly, ALDH ${ }^{\text {high }}$ cervical cancer cells could differentiate and reconstitute the cellular hierarchy in vitro and in vivo. After 2 weeks of culture in medium containing $\mathrm{FBS}, \mathrm{ALDH}^{\text {high }}$ cells differentiated into many $\mathrm{ALDH}^{\text {low }}$ cells, while $\mathrm{ALDH}^{\text {low }}$ cells generated few ALDH ${ }^{\text {high }}$ cells and predominantly maintained the ALDH ${ }^{\text {low }}$ phenotype (Figure 4A-4D). The ALDH1-positive population could be detected in all of the tumor xenograft tissues formed by the ALDH ${ }^{\text {high }}$ cells, but no ALDH1-positive cells were found in the tumors formed by the ALDH ${ }^{\text {low }}$ cells (Figure $4 \mathrm{E})$. Therefore, only the ALDH ${ }^{\text {high }}$ cells, not the ALDH ${ }^{\text {low }}$ cells, could differentiate and re-establish the cellular hierarchy in vitro and in vivo. Thirdly, $\mathrm{ALDH}^{\text {high }}$ cervical cancer cells had tumor initiating capacity in vivo. The tumors formed by the $\mathrm{ALDH}^{\text {high }}$ cells were larger and grew faster than those derived from the ALDH ${ }^{\text {low }}$ cells (Figure 3A). A shorter tumor-free period and a lower tumor-free rate were observed in mice injected with the $\mathrm{ALDH}^{\text {high }}$ cells than in mice injected with $\mathrm{ALDH}^{\text {low }}$ cells (Figure 3B). The tumor-initiating frequency of the ALDH ${ }^{\text {high }}$ cells was significantly higher than that of the ALDH ${ }^{\text {low }}$ cells (Table 1). Taken together, these data indicate that the $\mathrm{ALDH}^{\text {high }}$ cells are indeed CSCs in cervical cancer, similar to the results of previous ALDH studies in other solid tumors $[29,30,33,34,36,41]$.

ALDH expression and activity has been reported to be significantly higher in taxane- and platinum-resistant ovarian cancer cell lines [40]. Rahadiani et al. have reported that $\mathrm{ALDH}^{\text {high }}$ endometrioid adenocarcinoma cells are more resistant to cisplatin treatment than $\mathrm{ALDH}^{\text {low }}$ cells [39]. In this study, the $\mathrm{ALDH}^{\text {high }}$ cells were more resistant to cisplatin treatment than the $\mathrm{ALDH}^{\text {low }}$ cells (Figure 5), suggesting that $\mathrm{ALDH}^{\text {high }} \mathrm{CCSCs}$ exhibit chemoresistance similar to the CSCs found in other solid tumors $[39,48]$. Surprisingly, the viability of the ALDH ${ }^{\text {high }}$ C33A cells was significantly enhanced following exposure to cisplatin (Figure $5 \mathrm{~B}$ and $\mathrm{C}$ ). We attribute this to stimulated proliferation or enhanced activity of succinic acid dehydrogenase, which is the enzyme activity measured by the MTT assay. Further experiments are necessary to clarify the mechanisms that underlie the enhanced viability of the $\mathrm{ALDH}{ }^{\text {high }} \mathrm{C} 33 \mathrm{~A}$ cells.

The direct isolation of CSCs from uncultured human primary colon [30] and prostate [34] cancer cells and sorting based on ALDH activity has been reported. $\mathrm{ALDH}^{\text {high }} \mathrm{CSCs}$ in breast cancer [29] and pancreatic cancer [37] have been successfully isolated from primary cancer xenografts established in mice. In the present study, uncultured primary cervical cancer cells were first used to investigate the tumorigenicity of the $\mathrm{ALDH}^{\text {high }}$ and the $\mathrm{ALDH}^{\text {low }}$ cells. Unfortunately, neither the ALDH ${ }^{\text {high }}$ nor the $\mathrm{ALDH}^{\text {low }}$ cells from primary cervical cancer resulted in tumors in NOD/SCID mice, similar as the report about ovarian cancer [40]. Three possibilities may contribute to the failure of CSC isolation directly from primary uncultured cervical cancer cells: (1) ALDH-positive noncancerous cells, including white blood cells, stromal cells or normal stem cells, were abundant in the primary cancer tissues and contaminated the cancerous cells during tumor formation; (2) all primary cervical cancer tissues obtained from surgery are likely below the clinical stage of II a, and most of these cancerous cells may be too fragile to be sorted; or (3) the cells may be not resilient enough to form tumors in NOD/SCID mice. In the present study, CSCs were isolated from 5 generations of cervical cancer serially xenografted in NOD/SCID mice but not from uncultured primary cervical cancer cells. The following 3 possibilities may explain this phenomenon: (1) After more than 5 serial xenograft generations in NOD/SCID mice, primary cervical cancer cells acquired the capacity to form tumors; this idea is consistent with the notion that cancer cells can acquire enhanced tumorigenicity through serial transplantation in mice. (2) In this study, only 5 of the 28 cases of primary cervical cancer (approximately $18 \%$ ) could successfully be serially transplanted for more than 5 generations in mice, indicating that the cancer cells 
in most primary cancer tissues were too fragile to form tumors in NOD/SCID mice. (3) The cells used for the tumor formation assay were isolated from tumorspheres, which decreases the likelihood of contamination with ALDH-positive non-cancerous cells from the primary cancer tissues.

ALDH1 has been reported to be a marker for normal mammary stem cells [29]. In this study, ALDH1 expression was found in the basal cells of normal cervical tissue (Figure 1A, upper panel). The basal cells were recognized to contain cervical stem cells. Therefore, ALDH1 may be a marker of normal cervical stem cells. Further experiments should be designed to isolate and test the ALDH1-positive cervical basal cells to verify whether ALDH1 can be used as a marker of normal cervical stem cells.

In summary, this report is the first to describe the use of high ALDH activity to isolate CSCs from cervical cancer cell lines and primary cervical cancer cells. These $\mathrm{ALDH}^{\text {high }}$ cervical cancer cells possess the ability to selfrenew and differentiate and have enhanced tumorigenicity. Additionally, these cells exhibit chemoresistance and express high levels of stem cell-related transcription factors. Based on this study, ALDH activity may be used as a cytoplasmic marker for CCSCs, and a target to explore novel strategies for diagnosis, prognosis and therapy.

\section{METHODS}

\section{Ethics Statement}

Investigation has been conducted in accordance with the ethical standards and according to the Declaration of Helsinki and according to national and international guidelines and has been approved by the review board of the First Affiliated Hospital of Xi'an Jiaotong University.

\section{Cell lines and culture conditions}

The human cervical cancer cell lines $\mathrm{SiHa}, \mathrm{C} 33 \mathrm{~A}$, CaSki and HT-3 were obtained from the American Type Culture Collection (ATCC; Manassas, VA). SiHa and C33A cells were cultured in Dulbecco's Modified Eagle Medium-high glucose (DMEM; Sigma-Aldrich, St. Louis, MO) supplemented with $10 \%$ fetal bovine serum (FBS; Invitrogen, Carlsbad, CA). CaSki and HT-3 cells were cultured in RPMI-1640 (Sigma-Aldrich) and McCoy's 5A medium (Sigma-Aldrich), respectively, supplemented with $10 \%$ FBS. All cell lines were maintained at $37^{\circ} \mathrm{C}$ in an atmosphere containing 5\% carbon dioxide.

\section{Human tissue specimens, primary cervical cancer tissue processing and xenograft lines}

A total of 17 normal cervical tissues and 53 cervical cancer tissues were obtained from the First Affiliated Hospital of Xi'an Jiaotong University. The procedures followed approved medical ethics practices, and the patients provided their informed consent before the specimens were collected. Fresh cervical cancer tissues were obtained from 28 patients after radical hysterectomy and used for xenograft experiments. Single cell suspension was generated by mincing and digesting the tissue with $100 \mathrm{U} / \mathrm{mL}$ collagenase IV (GIBCO, Grand Island, NY) in basal medium at $37^{\circ} \mathrm{C}$ overnight. Xenograft lines were established by subcutaneous implantation of the primary cervical cancer cells in 6- to 8-week old NOD/SCID mice (Charles River Laboratories, Wilmington, MA). Once established, the solid tumor xenografts were serially passaged using the same technique.

\section{Immunohistochemistry (IHC)}

Formalin-fixed and paraffin-embedded tissue specimens were sliced into $4 \mathrm{~mm}$ sections, which were then deparaffinized and hydrated. An endogenous antigen retrieval procedure was performed using citric acid buffer $(10 \mathrm{mmol} / \mathrm{L}$ citrate buffer, $\mathrm{pH}$ 6.0). The slides were incubated with a mouse monoclonal antibody raised against human ALDH1 (BD Biosciences, Franklin Lakes, $\mathrm{NJ}$ ) or Ki67 (Santa Cruz, CA) overnight at $4^{\circ} \mathrm{C}$, then with secondary antibodies for $30 \mathrm{~min}$ at room temperature, followed by diaminobenzidine development. All slides were examined under an Olympus-CX31 microscope (Olympus, Tokyo, Japan).

\section{Flow cytometry analysis and FACS isolation of cells}

The ALDH enzymatic activity of the cells was measured using the ALDEFLUOR kit (Stem Cell Technologies, Vancouver, BC, Canada), according to the manufacturer's instructions. The brightly fluorescent ALDH-expressing cells were detected using a FACSCalibur or FACSAria flow cytometer (BD Biosciences). As a negative control, cells were stained under identical conditions after treatment with the specific ALDH inhibitor diethylaminobenzaldehyde (DEAB). The data were analyzed using FlowJo software (Tree Star Inc., Ashland, USA). For FACS, the cells were labeled using the ALDEFLUOR kit and sorted using a FACSAria cell sorter (BD Biosciences). 


\section{Tumorsphere culture}

Cells were maintained in stem cell media consisting of DMEM/F12 basal media, N2 and B27 supplements (Invitrogen), $20 \mathrm{ng} / \mathrm{mL}$ human recombinant epidermal growth factor (EGF) and $20 \mathrm{ng} / \mathrm{mL}$ basic fibroblastic growth factor (bFGF; PeproTech Inc., Rocky Hill, NJ). For the tumorsphere formation assay, cells were plated at a density of 200 cells/well in 24-well ultra-low attachment plates or at a density of 1 cell/well in 96-well plates and maintained in stem cell medium. Tumorspheres that arose within 2 weeks were recorded. For serial tumorsphere formation assays, the spheres were harvested, disaggregated with $0.25 \%$ trypsin/EDTA, filtered through a $40 \mu \mathrm{m}$ mesh and re-plated as described above. For each cell type, triplicate samples were done and the spheres were counted by two individuals in a blind fashion.

\section{Western blot}

Cells were lysed in a lysis buffer $(50 \mathrm{mM}$ Tris- $\mathrm{HCl}$, pH 7.4; $150 \mathrm{mM} \mathrm{NaCl} ; 2$ mM EDTA; $1 \%$ NP-40; and $0.1 \%$ sodium dodecyl sulfate) that contained a protease inhibitor cocktail (Complete Mini; Roche Diagnostics, Branchburg, NJ). The membranes were incubated with antibodies raised against ALDH1 (BD Biosciences), BMI1 (Millipore, Billerica, Mass), OCT4 (Santa Cruz), KLF4 (Santa Cruz) and GAPDH (Santa Cruz) at $4^{\circ} \mathrm{C}$ overnight, followed by a secondary incubation with horseradish peroxidase-conjugated immunoglobulin G (IgG; Thermo Fisher Scientific, New York, NY). The membranes were briefly incubated with an enhanced chemiluminescence reagent (Millipore, Billerica, Mass), then visualized on $\mathrm{x}$-ray films.

\section{Drug resistance and MTT assay}

For drug resistance assays, cells were plated in 96well plates at a density of $10^{4}$ cells/well and allowed to recover overnight before initiating drug treatments. The cells were exposed to various concentrations of cisplatin $(0,3,6,12,24$, or $48 \mu \mathrm{g} / \mathrm{mL}$ for $\mathrm{SiHa}$ and C33A cells or $0,0.5,1,2,4$, or $8 \mu \mathrm{g} / \mathrm{mL}$ for CaSki and HT-3 cells) for $24 \mathrm{~h}$, and the cell viability was measured. In separate experiments, the cells were exposed to a constant concentration of cisplatin $(3 \mu \mathrm{g} / \mathrm{mL}$ for $\mathrm{SiHa}$ and C33A cells or $1 \mu \mathrm{g} / \mathrm{mL}$ for CaSki and HT-3 cells) for 24,48 or $72 \mathrm{~h}$, and the cell viability was measured.

Cell viability was assessed using a 3-(4, 5-Dimethyl-1, 3-thiazol-2-yl)-2, 5-diphenyl-2H-tetrazol-3ium bromide (MTT; Sigma-Aldrich) assay. Following the manufacturer's instructions, $20 \mu \mathrm{L}$ of MTT solution were added to $200 \mu \mathrm{L}$ of the culture media. The plates were then incubated for $4 \mathrm{~h}$ at $37^{\circ} \mathrm{C}$, and the optical density was measured at $490 \mathrm{~nm}$.

\section{In vivo tumor formation assays}

The ALDH $^{\text {high }}$ and ALDH $^{\text {low }}$ cells were sorted, re-suspended in $200 \mu \mathrm{L}$ of 1:1 PBS/Matrigel (BD Biosciences) and injected subcutaneously into the flanks of 6- to 8-wk old female NOD/SCID mice; the left flank of the mouse received the ALDH ${ }^{\text {high }}$ cells, whereas the right flank received the $\mathrm{ALDH}^{\text {low }}$ cells. Engrafted mice were inspected twice per week by visual observation and palpation for the appearance of tumors. The tumor volume (V) was determined from the length (a) and the width (b) of the tumor, using the formula $\mathrm{V}=\mathrm{ab}^{2} / 2$ [49]. A portion of each tumor tissue was fixed in $10 \%$ formaldehyde and embedded in paraffin for IHC analysis. The frequency of tumorigenic cells (estimated with upper-lower limits) was calculated by limiting-dilution analysis [50].

\section{Statistical analysis}

Statistical analyses were performed using GraphPad Prism 5.01 software (La Jolla, CA, USA). In comparisons of 2 groups, Student's $t$-test was used to determine the statistical significance. To examine differences among 3 groups, an ANOVA analysis was performed. KaplanMeier survival analysis was performed and survival curve comparison analyses were performed using the log-rank (Mantel-Cox) test. P values of $\leq 0.05$ were regarded as statistically significant.

\section{ACKNOWLEDGEMENTS}

This research was supported by a grant for Distinguished Young Scientists (No. 30725043) from the National Natural Science Foundation of China.

\section{REFERENCES}

1. Jemal A, Bray F, Center MM, Ferlay J, Ward E and Forman D. Global cancer statistics. CA Cancer J Clin. 2011; 61(2):69-90.

2. Ferlay J, Shin HR, Bray F, Forman D, Mathers C and Parkin DM. Estimates of worldwide burden of cancer in 2008: GLOBOCAN 2008. Int J Cancer. 2010; 127(12):28932917.

3. Walboomers JM, Jacobs MV, Manos MM, Bosch FX, Kummer JA, Shah KV, Snijders PJ, Peto J, Meijer CJ and Munoz N. Human papillomavirus is a necessary cause of invasive cervical cancer worldwide. J Pathol. 1999; 189(1):12-19.

4. Bosch FX, Lorincz A, Munoz N, Meijer CJ and Shah KV. The causal relation between human papillomavirus and cervical cancer. J Clin Pathol. 2002; 55(4):244-265. 
5. Carter JR, Ding Z and Rose BR. HPV infection and cervical disease: a review. Aust N Z J Obstet Gynaecol. 2011; 51(2):103-108.

6. Rosa DD, Medeiros LR, Edelweiss MI, Pohlmann PR and Stein AT. Adjuvant platinum-based chemotherapy for early stage cervical cancer. Cochrane Database Syst Rev. 2012; 6:CD005342.

7. Scatchard K, Forrest JL, Flubacher M, Cornes P and Williams C. Chemotherapy for metastatic and recurrent cervical cancer. Cochrane Database Syst Rev. 2012; 10:CD006469.

8. Jin XW, Sikon A and Yen-Lieberman B. Cervical cancer screening: Less testing, smarter testing. Cleve Clin J Med. 2011; 78(11):737-747.

9. Reya T, Morrison SJ, Clarke MF and Weissman IL. Stem cells, cancer, and cancer stem cells. Nature. 2001; 414(6859):105-111.

10. Bonnet D and Dick JE. Human acute myeloid leukemia is organized as a hierarchy that originates from a primitive hematopoietic cell. Nat Med. 1997; 3(7):730-737.

11. Al-Hajj M, Wicha MS, Benito-Hernandez A, Morrison SJ and Clarke MF. Prospective identification of tumorigenic breast cancer cells. Proc Natl Acad Sci U S A. 2003; 100(7):3983-3988.

12. Singh SK, Hawkins C, Clarke ID, Squire JA, Bayani J, Hide T, Henkelman RM, Cusimano MD and Dirks PB. Identification of human brain tumour initiating cells. Nature. 2004; 432(7015):396-401.

13. Fang D, Nguyen TK, Leishear K, Finko R, Kulp AN, Hotz S, Van Belle PA, Xu X, Elder DE and Herlyn M. A tumorigenic subpopulation with stem cell properties in melanomas. Cancer Res. 2005; 65(20):9328-9337.

14. Matsui W, Huff CA, Wang Q, Malehorn MT, Barber J, Tanhehco Y, Smith BD, Civin CI and Jones RJ. Characterization of clonogenic multiple myeloma cells. Blood. 2004; 103(6):2332-2336.

15. Collins AT, Berry PA, Hyde C, Stower MJ and Maitland NJ. Prospective identification of tumorigenic prostate cancer stem cells. Cancer Res. 2005; 65(23):10946-10951.

16. O'Brien CA, Pollett A, Gallinger S and Dick JE. A human colon cancer cell capable of initiating tumour growth in immunodeficient mice. Nature. 2007; 445(7123):106-110.

17. Ricci-Vitiani L, Lombardi DG, Pilozzi E, Biffoni M, Todaro M, Peschle C and De Maria R. Identification and expansion of human colon-cancer-initiating cells. Nature. 2007; 445(7123):111-115.

18. Prince ME, Sivanandan R, Kaczorowski A, Wolf GT, Kaplan MJ, Dalerba P, Weissman IL, Clarke MF and Ailles LE. Identification of a subpopulation of cells with cancer stem cell properties in head and neck squamous cell carcinoma. Proc Natl Acad Sci U S A. 2007; 104(3):973978.

19. Prince ME and Ailles LE. Cancer stem cells in head and neck squamous cell cancer. J Clin Oncol. 2008;
26(17):2871-2875.

20. Li C, Heidt DG, Dalerba P, Burant CF, Zhang L, Adsay V, Wicha M, Clarke MF and Simeone DM. Identification of pancreatic cancer stem cells. Cancer Res. 2007; 67(3):10301037.

21. Tirino V, Desiderio V, Paino F, De Rosa A, Papaccio F, La Noce M, Laino L, De Francesco F and Papaccio G. Cancer stem cells in solid tumors: an overview and new approaches for their isolation and characterization. FASEB J. 2013; 27(1):13-24.

22. Vasiliou V, Pappa A and Estey T. Role of human aldehyde dehydrogenases in endobiotic and xenobiotic metabolism. Drug Metab Rev. 2004; 36(2):279-299.

23. Sladek NE. Human aldehyde dehydrogenases: potential pathological, pharmacological, and toxicological impact. J Biochem Mol Toxicol. 2003; 17(1):7-23.

24. Hilton J. Role of aldehyde dehydrogenase in cyclophosphamide-resistant L1210 leukemia. Cancer Res. 1984; 44(11):5156-5160.

25. Kastan MB, Schlaffer E, Russo JE, Colvin OM, Civin CI and Hilton J. Direct demonstration of elevated aldehyde dehydrogenase in human hematopoietic progenitor cells. Blood. 1990; 75(10):1947-1950.

26. Moreb JS, Schweder M, Gray B, Zucali J and Zori R. In vitro selection for K562 cells with higher retrovirally mediated copy number of aldehyde dehydrogenase class-1 and higher resistance to 4-hydroperoxycyclophosphamide. Hum Gene Ther. 1998; 9(5):611-619.

27. Sladek NE. Aldehyde dehydrogenase-mediated cellular relative insensitivity to the oxazaphosphorines. Curr Pharm Des. 1999; 5(8):607-625.

28. Cheung AM, Wan TS, Leung JC, Chan LY, Huang $\mathrm{H}$, Kwong YL, Liang $\mathrm{R}$ and Leung AY. Aldehyde dehydrogenase activity in leukemic blasts defines a subgroup of acute myeloid leukemia with adverse prognosis and superior NOD/SCID engrafting potential. Leukemia. 2007; 21(7):1423-1430.

29. Ginestier C, Hur MH, Charafe-Jauffret E, Monville F, Dutcher J, Brown M, Jacquemier J, Viens P, Kleer CG, Liu S, Schott A, Hayes D, Birnbaum D, Wicha MS and Dontu G. ALDH1 is a marker of normal and malignant human mammary stem cells and a predictor of poor clinical outcome. Cell Stem Cell. 2007; 1(5):555-567.

30. Huang EH, Hynes MJ, Zhang T, Ginestier C, Dontu G, Appelman H, Fields JZ, Wicha MS and Boman BM. Aldehyde dehydrogenase 1 is a marker for normal and malignant human colonic stem cells (SC) and tracks SC overpopulation during colon tumorigenesis. Cancer Res. 2009; 69(8):3382-3389.

31. Carpentino JE, Hynes MJ, Appelman HD, Zheng T, Steindler DA, Scott EW and Huang EH. Aldehyde dehydrogenase-expressing colon stem cells contribute to tumorigenesis in the transition from colitis to cancer. Cancer Res. 2009; 69(20):8208-8215. 
32. Chu P, Clanton DJ, Snipas TS, Lee J, Mitchell E, Nguyen ML, Hare E and Peach RJ. Characterization of a subpopulation of colon cancer cells with stem cell-like properties. Int J Cancer. 2009; 124(6):1312-1321.

33. Su Y, Qiu Q, Zhang X, Jiang Z, Leng Q, Liu Z, Stass SA and Jiang F. Aldehyde dehydrogenase 1 A1-positive cell population is enriched in tumor-initiating cells and associated with progression of bladder cancer. Cancer Epidemiol Biomarkers Prev. 2010; 19(2):327-337.

34. van den Hoogen C, van der Horst G, Cheung H, Buijs JT, Lippitt JM, Guzman-Ramirez N, Hamdy FC, Eaton CL, Thalmann GN, Cecchini MG, Pelger RC and van der Pluijm G. High aldehyde dehydrogenase activity identifies tumorinitiating and metastasis-initiating cells in human prostate cancer. Cancer Res. 2010; 70(12):5163-5173.

35. Qin J, Liu X, Laffin B, Chen X, Choy G, Jeter CR, CalhounDavis T, Li H, Palapattu GS, Pang S, Lin K, Huang J, Ivanov I, Li W, Suraneni MV and Tang DG. The PSA(-/ lo) prostate cancer cell population harbors self-renewing long-term tumor-propagating cells that resist castration. Cell Stem Cell. 2012; 10(5):556-569.

36. Sullivan JP, Spinola M, Dodge M, Raso MG, Behrens C, Gao B, Schuster K, Shao C, Larsen JE, Sullivan LA, Honorio S, Xie Y, Scaglioni PP, DiMaio JM, Gazdar AF, Shay JW, et al. Aldehyde dehydrogenase activity selects for lung adenocarcinoma stem cells dependent on notch signaling. Cancer Res. 2010; 70(23):9937-9948.

37. Kim MP, Fleming JB, Wang H, Abbruzzese JL, Choi W, Kopetz S, McConkey DJ, Evans DB and Gallick GE. ALDH activity selectively defines an enhanced tumorinitiating cell population relative to CD133 expression in human pancreatic adenocarcinoma. PLoS One. 2011; 6(6):e20636.

38. Clay MR, Tabor M, Owen JH, Carey TE, Bradford CR, Wolf GT, Wicha MS and Prince ME. Single-marker identification of head and neck squamous cell carcinoma cancer stem cells with aldehyde dehydrogenase. Head Neck. 2010; 32(9):1195-1201.

39. Rahadiani N, Ikeda J, Mamat S, Matsuzaki S, Ueda Y, Umehara R, Tian T, Wang Y, Enomoto T, Kimura T, Aozasa $\mathrm{K}$ and Morii E. Expression of aldehyde dehydrogenase 1 (ALDH1) in endometrioid adenocarcinoma and its clinical implications. Cancer Sci. 2011; 102(4):903-908.

40. Landen CN, Jr., Goodman B, Katre AA, Steg AD, Nick AM, Stone RL, Miller LD, Mejia PV, Jennings NB, Gershenson DM, Bast RC, Jr., Coleman RL, Lopez-Berestein G and Sood AK. Targeting aldehyde dehydrogenase cancer stem cells in ovarian cancer. Mol Cancer Ther. 2010; 9(12):31863199.

41. Luo Y, Dallaglio K, Chen Y, Robinson WA, Robinson SE, McCarter MD, Wang J, Gonzalez R, Thompson DC, Norris DA, Roop DR, Vasiliou V and Fujita M. ALDH1A isozymes are markers of human melanoma stem cells and potential therapeutic targets. Stem Cells. 2012; 30(10):2100-2113.
42. Rao QX, Yao TT, Zhang BZ, Lin RC, Chen ZL, Zhou H, Wang LJ, Lu HW, Chen Q, Di N and Lin ZQ. Expression and functional role of ALDH1 in cervical carcinoma cells. Asian Pac J Cancer Prev. 2012; 13(4):1325-1331.

43. Yao T, Chen Q, Zhang B, Zhou H and Lin Z. The expression of ALDH1 in cervical carcinoma. Med Sci Monit. 2011; 17(8):HY21-26.

44. Bortolomai I, Canevari S, Facetti I, De Cecco L, Castellano G, Zacchetti A, Alison MR and Miotti S. Tumor initiating cells: development and critical characterization of a model derived from the A431 carcinoma cell line forming spheres in suspension. Cell Cycle. 2010; 9(6):1194-1206.

45. Deng S, Yang X, Lassus H, Liang S, Kaur S, Ye Q, Li C, Wang LP, Roby KF, Orsulic S, Connolly DC, Zhang Y, Montone K, Butzow R, Coukos G and Zhang L. Distinct expression levels and patterns of stem cell marker, aldehyde dehydrogenase isoform 1 (ALDH1), in human epithelial cancers. PLoS One. 2010; 5(4):e10277.

46. Al-Ejeh F, Smart CE, Morrison BJ, Chenevix-Trench G, Lopez JA, Lakhani SR, Brown MP and Khanna KK. Breast cancer stem cells: treatment resistance and therapeutic opportunities. Carcinogenesis. 2011; 32(5):650-658.

47. Todaro M, Iovino F, Eterno V, Cammareri P, Gambara G, Espina V, Gulotta G, Dieli F, Giordano S, De Maria R and Stassi G. Tumorigenic and metastatic activity of human thyroid cancer stem cells. Cancer Res. 2010; 70(21):88748885 .

48. Nishikawa S, Konno M, Hamabe A, Hasegawa S, Kano Y, Ohta K, Fukusumi T, Sakai D, Kudo T, Haraguchi N, Satoh T, Takiguchi S, Mori M, Doki Y and Ishii H. Aldehyde dehydrogenasehigh gastric cancer stem cells are resistant to chemotherapy. Int J Oncol. 2013; 42(4):1437-1442.

49. Zhang Y, Li B, Ji ZZ and Zheng PS. Notch1 regulates the growth of human colon cancers. Cancer. 2010; 116(22):5207-5218.

50. $\mathrm{Hu}$ Y and Smyth GK. ELDA: extreme limiting dilution analysis for comparing depleted and enriched populations in stem cell and other assays. J Immunol Methods. 2009; 347(1-2):70-78. 